\title{
The Relation between Organizational Effectiveness, Relationship and Organizational Culture of Financial Industry Employees in Korea and Moderating Effect of Job Characteristic
}

\author{
Boine KIM \\ Associate Professor, Department of Global Commerce, Hoseo University, South Korea \\ E-mail: bk130@naver.com
}

Received: 25 August 2020. Revised: 03 September 2020. Accepted: 06 September 2020.

\begin{abstract}
Purpose - As the interest of financial aria increase in economic change and labor market change, this study focused on the employee of the financial aria in Korea. The purpose of this study is to analyses relation among relationship variable and organizational culture variable and organizational effectiveness of financial aria employees in Korea.
\end{abstract}

Research design, data, and methodology - This study measured relationship variable with communication and trust. And measured organizational culture variable with innovation, relation, hierarchy and rational. And measured organizational effectiveness with job satisfaction and organizational commitment. Empirical analysis is conducted using 442 financial aria employees of 7th HCCP in KRIVET. And SPSS is used in frequency and stepwise regression test and AMOS is used in path analysis with group differentiation test.

Results - Overall results show that trust and relation culture give positive influence on job satisfaction. Organizational commitment results show that relation culture and rational culture give positive influence and also job satisfaction. However, hierarchy culture gives negative influence on organizational commitment. Also, the moderating effect of work characteristics is significant.

Conclusions -Result of this study give managerial implication to HRM and also expend inflected organizational culture study to financial aria in Korea. Especially gives insight to relationship, organizational culture and organizational effectiveness. And management differentiation needs between work characteristic.

Keywords : organizational effectiveness, financial aria employee, organizational culture variable, relationship variable, HCCP

JEL Classification Code : M12, M14, M19

(c) Copyright: The Author(s)

This is an Open Access article distributed under the terms of the Creative Commons Attribution Non-Commercial License (http://Creativecommons.org/licenses/by-nc/4.0/) which permits unrestricted noncommercial use, distribution, and reproduction in any medium, provided the original work is properly cited. 


\section{Introduction}

The whole world is going through the fourth industrial revolution, pandemic and untact environmental change, etc. Also, long term economic depression is ongoing. This circumstance makes a dramatic change in the business environment. In this changing environment, researches are mostly focused on manufacturing (Hofsetter \& Harpaz, 2015) or some in service (Hogan \& Coote, 2014; Sarhan et al., 2020; Mesfin et al., 2020). However financial aria needs more attention (Chu \& Jung, 2002). In Korea economic, financial aria takes 5\% of GDP (gross domestic product). And according to the MOEL (ministry of employment and labor) in 2018, finance and insurance aria includes 39 thousand businesses with 710 thousand employees are working. As economic policy plans to increase financial aria into the central role of economic growth and change in inner financial aria, also in the labor market interest more study needs financial area. Therefore, this study focuses on the employee of financial aria in Korea and there HRM (human resource management) related recognition.

Based on the literature review, this study analyses relation between relationship variable and organizational culture variable and organizational effectiveness. This study measured relationship variable as communication and trust. And measured organizational culture variable as innovation, relation, hierarchy and rational. And measured organizational effectiveness with job satisfaction and organizational commitment. This study empirical analysis is conducted using the seventh HCCP (human capital corporate panel) of 442 financial aria employees in KRIVET (Korea research institute for vacation \& training). SPSS (statistical package for social science) is used in frequency test and stepwise regression test and AMOS (analysis of moment structure) is used in path analysis with group differentiation test. The result of this study extends the research aria to financial service are and also could give managerial implication to effective HRM in financial employee management.

\section{Literature Review and Hypothesis}

\subsection{Theorical Background}

\subsubsection{Organizational Culture Variable}

In general, culture is socially educated and total mixture meaning of shared value, faith, way of thinking, virtue, custom, etc(Williams, 1983). Therefore, organizational culture reflects the shared value and custom of an organization also grant separate identification to organization different from other organization (Schein, 1985; Robbins, 1998). Literature shows that it could influence grate deal to employee behavior patterns and belief systems (Griffin \& Moorhead, 2009). And organizational culture in circumstance promotes organizational effectiveness which is evaluated as job satisfaction, organizational commitment and others (Vilnai-Yavetz et al. 2005; Hongan \& Coote 2014,). Studies of organizational culture approach could be summarized as trait approach, culture strength approach, culture type approach, contingency approach (Kim, 2000; Kim, 2007). Studies show that organizational culture type approach empirically analyzes organizational culture and problem circumstance of organization (Quinn \& Kimberly, 1984; Cameron, 1985; Zammuto \& Krakowe, 1991; Aycan et al. 1999; Parker \& Bradley, 2000; Lee \& Lee, 2008).

In this rapidly changing business environment, this study wants to understand multi and diver organizational culture, culture type approach of Quin and Kimberly (1984) is used. Quin and Kimberly (1984)'s organizational culture includes four dimensions of culture; innovation, relation, hierarchy and rational. First, innovation culture is called open system model. Based on the change, innovation culture emphasis flexibility, adapt to circumstance and pursues innovation (Zammuto \& Krakower, 1991; Cameron \& Quinn, 2011). Grow through adventure and challenge, aim employees to innovate and create also culture that backup this new idea development, resource acquisition (Jassawalla \& Sashittal, 2002). Second, relation culture is called human relation model which take interest in internally formed human network (Parker \& Bradley, 2000). Relation culture values trust, teamwork, loyalty, bond with members. Focus on the increase of organizational cohesion, participation and commitment (Choi, 2005). Third, hierarchy culture is called internal process model. Base on stable organization, hierarchy culture pursues standardized business management and efficiency improvement (Zammuto \& Krakower, 1991). Clear hierarchy order, formal reporting system, standardized management and strict control is normal also an emphasis on integration of organization (Ju \& Sun, 2018). Fourth, rational culture is called the rational goal model. Rational culture values achieving a reasonable goal, reserve competitiveness, increase productivity by efficient task fulfillment (Choi, 2005). 


\subsubsection{Relationship Variable}

In this study, relationship variable includes two construct communication and trust, which in internal marketing. Communication is a share of information in time it includes formal and informal communication. To do a job efficiently and effectively, an efficient and continuous share of information requires communication. Trust is individual's reliance of person or thing, and organizational trust it is a belief that action of organization gives benefit to organization member (Tan \& Tan, 200; Spence et al., 2001). Trust includes employee and employer, it involves trust relation with the manager, relation with the job as self-respect pride, relation with a coworker and other aspects (Levering, 2000). Trust is critical to both self-development and interpersonal relationships. Trust comes from employee's attitudes toward organization trust and relation between inner members (Kiffin-Petersen \& Cordery, 2003). When trust is high which implicate employee have high hope, faith, assurance toward organization enable systemic interaction within the organization which leads to organizational performance. When trust is low, the employee has doubts, fear, wariness toward the organization make them think that they will be sucked in or not be rewarded fairly.

Communication and trust are highly interactive (Guzley, 1992; Ruppel \& Harrington, 2000). Trust is needed to communicate and when implementing communication's conclusion (Rosli \& Hussein, 2008). Also, communication is needed to build clear trust (Anderson \& Narus, 1984; Allert \& Chatterjee, 1997; de Ridder, 2006).

\subsubsection{Organization Effectiveness Variable}

Organizational effectiveness is one of organization performance index which shows organization goal achievement or efficient management state (Etzioni, 1960; Price, 1972). Studies of organizational effectiveness are diverse which include economic performance, psychological performance, organizational management performance, or employee behavioral performance. A performance measure used productivity, profitability, turnover rate, adaptability, job satisfaction organizational commitment, etc(Price, 1972; Steers, 1975 \& 1977; Campbell, 1977; Cameron, 1985). Among many organizational effectiveness, job satisfaction organizational commitment is easy to apply to person, group and organization level also studies show that both are well accepted and used in literature. Job satisfaction is an employee's positive emotional state or joy from a job or job experience (Hoppock, 1935; Locke, 1969; Price \& Mueller, 1986). Job satisfaction relates to the character of the job, the fulfilment of personal need toward the job, the environment of working condition therefore representative antecedent of job satisfaction is organization variables like policy, organizational structure, culture also job environment variables like relation with coworker, job scope, job ambiguity or conflict, etc(Herzberg et al., 1959; Meyer, 1964; Vroom, 1964; Porter \& Steers, 1974; Locke, 1976; Ginzberg, 1981).

Based on the emotional unity of employee toward their organization, organizational commitment support organization goal and attitude to sustain employment state to continue (Buchanan, 1974; Allen \& Meyer, 1990). Organizational commitment reflects positive attitude toward their organization (O'Reilly \& Chatman, 1986), equate them and organization and proactively participate in organization problem (Osborne et al., 1980). The representative antecedent of organizational commitment is personal variable like achievement need, job variable like autonomy and work identity also work environment variable like organization support, management system, leadership and cultural character (Steers, 1977; Stevens, 1977; Stevens et al., 1978; Mowday et al., 1979).

\subsection{Relation between Variable and Hypotheses}

Studies show the influence of each organizational culture dimension on organization effectiveness (Jaskyte \& Dressler, 2004; Deutschman, 2005). Even though organizational culture dimension seems mutually exclusive, due to its different character, a balanced dimension gives positive influence on employee job execution and efficient organization process management (Hofstetter \& Harpax, 2015). And studies show that as personal fitness feels with organization culture increase job satisfaction and organizational commitment (O'Reilly et al., 1991). Also, studies have shown that organizational culture affects job satisfaction (Robbins, 1998; Kraut, 1998; Bellou, 2010; Tsai, 2011; Belias \& Koustelios, 2014).

H 1-1: Innovation culture will positively influence organizational effectiveness.

H 1-2: Relation culture will positively influence organizational effectiveness. 
H 1-3: Hierarchy culture will positively influence organizational effectiveness.

H 1-4: Rational culture will positively influence organizational effectiveness.

Communication and trusty significantly influence job performance, job satisfaction (Pincus, 1986), and organizational commitment (Boshoff \& Tait, 1996). Self-fulfilling prophecy theory and norm reciprocity theory explain relation (Skarlicki \& Dirks, 2001). According to the self-fulfilling prophecy theory, employees become what managers expect from them. If managers expect employees to be trustworthy and communicative, they try to do accordingly until they are told not to do. Also, according to the norm of reciprocity theory, employees try to reciprocate the benefits they received. Trust of the organization strengthens competitive advantage also the unity of the organization arises so members focus on organization goal. And base on the exchange theory, level of effort and devotion are different by trust level which differentiates organization performance (Aryee et al., 2002). Low trust lead to negative organization performance (Levering, 2000; Kiffin-Petersen \& Cordery, 2003; Renzl, 2008) and job satisfaction (Belicki \& Woolcott, 1996; Dirks \& Ferrin, 2002).

H 2-1: Communication will positively influence organizational effectiveness.

H 2-2: Trust will positively influence organizational effectiveness.

In this study organizational effectiveness is measured with job satisfaction and organizational commitment. And one of the purposes of this study is to analyze whether job satisfaction mediates the relation between antecedent and organizational commitment. Studies have been shown that as job satisfaction increases they try to contribute more to the organization and try to stay in the same organization (Cote \& Morgan, 2002).

H 3: Job satisfaction will be mediate between the independent variables and organizational commitment.

Also, in this study, exploratory analysis work characteristic as a moderator to verify whether differentiation is necessary for managing each work characteristic group. Work characteristic is measured with routines of work.

H 4: Work characteristic moderate relation between variables.

\section{Research Methodology}

\subsection{Research Model}

Based on the literature, three main analyses are conducted in this study and Figure 1 shows the research model. First, relation analysis among variables. Two independent variables are analyzed, relationship and organizational culture. And one dependent variable is analyzed-organizational effectiveness. Relationship variable included two subvariables, communication and trust. Organizational culture variable includes four sub-variables, aim for innovation, aim for relation, aim for hierarchy and aim for rational. And organizational effectiveness includes two sub-variables, job satisfaction and organizational commitment. Second, this study analyzes the mediating effect of job satisfaction between independent variables and organizational commitment. And finally, third, this study exploratory include moderating effect of work characteristic. Work characteristics implicate how employee characterize their work from routinely repeat, often exceptional, sometimes exceptional to ever day novelty.

Subject participated a questionnaire including demographics including gender, age, education, tenure, rank, industry and work characteristic. And measures of the following variables as five-point Likert scale: relationshipcommunication and trust, organizational culture-innovation, relation, hierarchy, rational, and job satisfaction, lastly, organizational commitment. Communication and trust are measured by three statements. Each of four organizational culture variables innovation, relation, hierarchy, rational is measured by three statements. Job satisfaction is measured by three statements. And organizational commitment is measured by four statements (For the complete scale, please see appendix 1) 


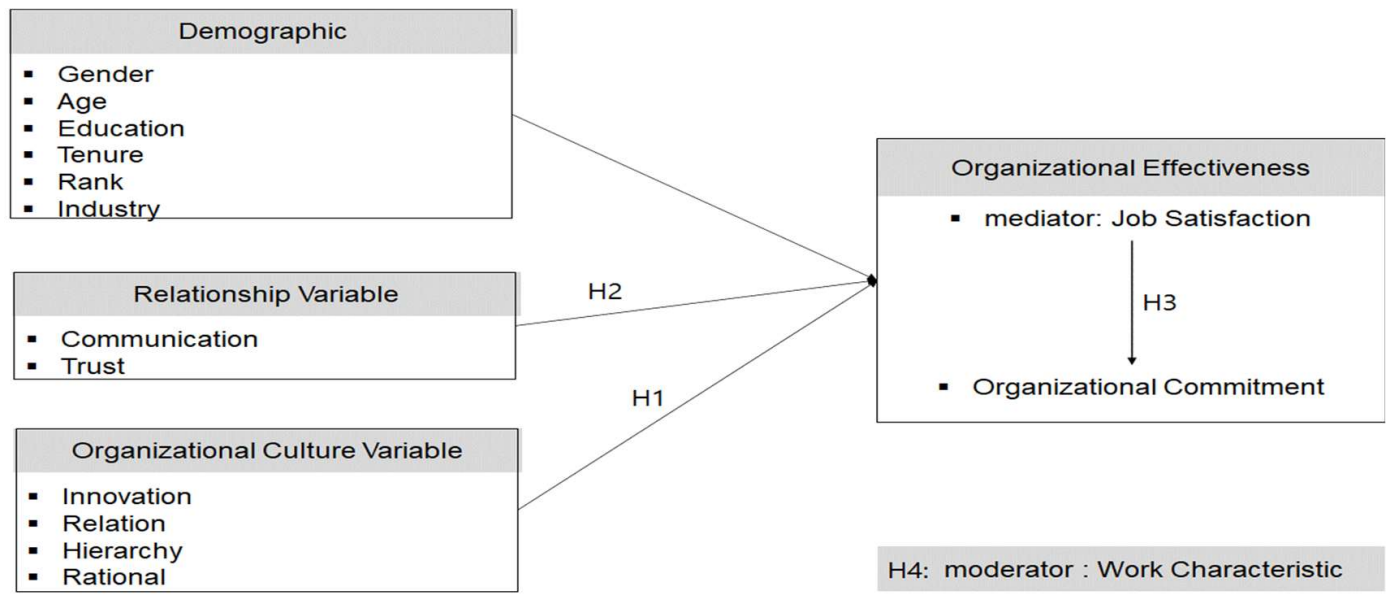

Figure 1: Research Model

\subsection{Research Sample}

This study used 442 financial aria employees of seventh HCCP (human capital corporate panel) in KRIVET(Korea research institute for vacation \& training) data which is collected in 2017 and expose in 2018. In Table 1, demographic characteristics are summarized.

Table 1: Demographic Characteristics

\begin{tabular}{|c|c|c|c|}
\hline & & $\mathbf{N}$ & $\%$ \\
\hline \multirow{3}{*}{ Industry } & Dummy 1-Finance & 169 & 38.2 \\
\hline & Dummy 2-Insurance \& Pension & 136 & 30.8 \\
\hline & Dummy 3- Finance \& Insurance Service & 137 & 31.0 \\
\hline \multirow{2}{*}{ Gender } & Female & 140 & 31.7 \\
\hline & Male & 302 & 68.3 \\
\hline Age & \multicolumn{3}{|c|}{ Mean(38.76), Middle(38.00), S.D.(7.22), Dispersion(53.15), Mini(23.00), Max(57.00) } \\
\hline \multirow{4}{*}{ Education } & High school & 18 & 4.1 \\
\hline & College & 39 & 8.8 \\
\hline & University & 340 & 76.9 \\
\hline & Graduate school & 45 & 10.2 \\
\hline Tenure & \multicolumn{3}{|c|}{ Mean(11.06), Middle(10.00), S.D.(6.92), Dispersion(47.82), Mini(1.00), Max(39.00) } \\
\hline \multirow{4}{*}{ Rank } & worker & 49 & 11.1 \\
\hline & first level manager & 143 & 32.4 \\
\hline & middle-level manager & 191 & 43.2 \\
\hline & senior manager & 59 & 13.3 \\
\hline \multirow{4}{*}{ Work Characteristic } & routinely repeat & 64 & 14.5 \\
\hline & often exceptional & 205 & 46.4 \\
\hline & sometimes exceptional & 151 & 34.2 \\
\hline & ever day novelty & 22 & 5.0 \\
\hline
\end{tabular}




\section{Statistical Result}

\subsection{Analysis of Reliability and Validity}

Measurement validity and reliability analysis are conducted before analyzing the relationship among variables and the result is summarized in Table 2. CFA (confirmative factor analysis) is analyzed to confirm measurement validity also CR (construct reliability) and AVE(averaged variance extracted) is calculated. Fitness of CFA result show CMIN 506.669, DF247, P.000, CMIN/DF( $\left.\chi^{2}\right)$ 2.051, NFI .920, IFI .958, CFI .957, RMSEA .049 which show good fit. Also, measurement validity is secured as all CR is larger than 0.7 and AVE is larger than 0.5(Bagozzi \& Yi, 1988). Reliability is also secured as all the Cronbach's $\alpha$ test results show larger than 0.6 which is acceptable (Nunnally \& Bernstein, 1994).

Table 2: Result of Measurement Reliability and Validity Analysis

\begin{tabular}{|c|c|c|c|c|c|c|}
\hline Variable & Item & Estimate & Factor & CR & AVE & Cronbach's $\alpha$ \\
\hline \multirow{3}{*}{ Communication } & $\mathrm{c} 1$ & $.809 *$ & \multirow{3}{*}{.479 * } & \multirow{3}{*}{.864} & \multirow{3}{*}{.681} & \multirow{3}{*}{.822} \\
\hline & $\mathrm{c} 2$ & .792* & & & & \\
\hline & $\mathrm{c3}$ & $.729 *$ & & & & \\
\hline \multirow[t]{3}{*}{ Trust } & $\mathrm{t} 1$ & $.835_{*}^{*}$ & \multirow{3}{*}{.470 * } & \multirow[t]{3}{*}{.905} & \multirow[t]{3}{*}{.761} & \multirow[t]{3}{*}{.857} \\
\hline & t2 & $.816 *$ & & & & \\
\hline & t3 & .799* & & & & \\
\hline \multirow{3}{*}{ Innovation } & i1 & $.735 *$ & \multirow{3}{*}{$.351 *$} & \multirow{3}{*}{.888} & \multirow{3}{*}{.744} & \multirow{3}{*}{.846} \\
\hline & i2 & $.871 *$ & & & & \\
\hline & i3 & $.802 *$ & & & & \\
\hline \multirow{3}{*}{ Relation } & $\mathrm{r} 1$ & .839粶 & \multirow{3}{*}{.427 粶 } & \multirow{3}{*}{.907} & \multirow{3}{*}{.765} & \multirow{3}{*}{.861} \\
\hline & r2 & .850 * & & & & \\
\hline & r3 & 768 * & & & & \\
\hline \multirow[t]{2}{*}{ Hierarchy } & h1 & $.681 *$ & \multirow[t]{2}{*}{$.323 *$} & \multirow[t]{2}{*}{.749} & \multirow[t]{2}{*}{.673} & \multirow[t]{2}{*}{.653} \\
\hline & $\mathrm{h} 2$ & $.710_{*}^{*}$ & & & & \\
\hline \multirow[t]{3}{*}{ Rational } & $\mathrm{j} 1$ & $.771 *$ & \multirow[t]{3}{*}{$.319 *$} & \multirow[t]{3}{*}{.836} & \multirow[t]{3}{*}{.599} & \multirow[t]{3}{*}{.730} \\
\hline & j2 & $.797 *$ & & & & \\
\hline & $\mathrm{j} 3$ & $.516 *$ & & & & \\
\hline \multirow[t]{4}{*}{ JS } & s1 & $.843 *$ & \multirow[t]{4}{*}{$.386 *$} & .926 & .760 & .863 \\
\hline & $\mathrm{s} 2$ & .659* & & & & \\
\hline & s3 & .739* & & & & \\
\hline & s4 & $.889 *$ & & & & \\
\hline OC & $\mathrm{c} 1$ & $.546 *$ & $.309 *$ & .794 & .622 & .749 \\
\hline & $\mathrm{c} 2$ & $.643 *$ & & & & \\
\hline & c3 & $.636 *$ & & & & \\
\hline & $\mathrm{c} 4$ & $.818 *$ & & & & \\
\hline & & $\begin{array}{r}\mathrm{MIN}=506.66 \\
\mathrm{NFI}=.920,\end{array}$ & $\begin{array}{l}47, \mathrm{P}=.0 \\
\mathrm{CFI}=.9\end{array}$ & $\begin{array}{l}\mathrm{N} / \mathrm{DF} \\
\mathrm{EA}=\end{array}$ & & \\
\hline
\end{tabular}

Note: $*$ * $<0.01, *<0.05, \mathrm{JS}=$ Job Satisfaction, $\mathrm{OC}=$ Organizational Commitment

\subsection{Causal Relation Analysis}

As measurement validity and reliability is confirmed above, the first causal relation analysis is continued by regression analysis of organizational effectiveness. Also, as this study include two organizational effectiveness, job satisfaction and organizational commitment, the mediating effect of job satisfaction is also analyzed. Second, this 
study analyzes the moderating effect of work characteristics is analyzed with path analysis by group comparison.

\subsubsection{Regression Analysis of Organizational Effectiveness}

Stepwise regression analysis is conducted to test causal relation among variables. In first step as model 1(M1) includes control variables; gender, age, education, tenure, rank, industry and work characteristic. In second step as model 2(M2) add relationship variables and organizational culture variables. For organizational commitment, there is third step as model 3(M3) which additionally includes job satisfaction to confirm the mediating effect of job satisfaction between independent variable and organizational commitment.

\begin{tabular}{|c|c|c|c|c|c|c|c|}
\hline \multirow{2}{*}{\multicolumn{2}{|c|}{$\begin{array}{c}\text { Dependent } \\
\text { Independent }\end{array}$}} & \multicolumn{2}{|c|}{ Job Satisfaction } & \multicolumn{3}{|c|}{ Organizational Commitment } & \multirow[t]{2}{*}{ Hypothesis } \\
\hline & & M1 & M2 & M1 & M2 & M3 & \\
\hline \multicolumn{2}{|l|}{ Gender } & $\begin{array}{c}.070 \\
(1.367) \\
\end{array}$ & $\begin{array}{c}.046 \\
(1.041) \\
\end{array}$ & $\begin{array}{c}.077 \\
(1.534) \\
\end{array}$ & $\begin{array}{c}.057 \\
(1.361) \\
\end{array}$ & $\begin{array}{c}.040 \\
(1.028) \\
\end{array}$ & \\
\hline \multicolumn{2}{|l|}{ Age } & $\begin{array}{c}-.048 \\
(-.532) \\
\end{array}$ & $\begin{array}{l}.001 \\
(.015)\end{array}$ & $\begin{array}{l}.013 \\
(.147)\end{array}$ & $\begin{array}{c}.056 \\
(.770) \\
\end{array}$ & $\begin{array}{l}.056 \\
(.832)\end{array}$ & \\
\hline \multicolumn{2}{|l|}{ Education } & $\begin{array}{c}.084 \\
(1.700) \\
\end{array}$ & $\begin{array}{c}.077 \\
(1.809) \\
\end{array}$ & $\begin{array}{c}.094 \\
(1.960) \\
\end{array}$ & $\begin{array}{c}.091^{*} \\
(2.262) \\
\end{array}$ & $\begin{array}{c}.062 \\
(1.671) \\
\end{array}$ & \\
\hline \multicolumn{2}{|l|}{ Tenure } & $\begin{array}{c}.113 \\
(1.622) \\
\end{array}$ & $\begin{array}{c}.112 \\
(1.875) \\
\end{array}$ & $\begin{array}{c}.124 \\
(1.833) \\
\end{array}$ & $\begin{array}{c}.122 * \\
(2.171) \\
\end{array}$ & $\begin{array}{c}.080 \\
(1.543) \\
\end{array}$ & \\
\hline \multicolumn{2}{|l|}{ Rank } & $\begin{array}{c}.037 \\
(.482)\end{array}$ & $\begin{array}{l}-.012 \\
(-.181)\end{array}$ & $\begin{array}{c}.115 \\
(1.539)\end{array}$ & $\begin{array}{c}.066 \\
(1.061)\end{array}$ & $\begin{array}{c}.071 \\
(1.235)\end{array}$ & \\
\hline \multicolumn{2}{|c|}{ Industry dummy 2} & $\begin{array}{c}-.243 * \\
(-4.617)\end{array}$ & $\begin{array}{c}-129 * \\
(-2.638)\end{array}$ & $\begin{array}{c}-.241 * \\
(-4.676)\end{array}$ & $\begin{array}{c}-.125 * \\
(-2.722)\end{array}$ & $\begin{array}{c}-.077 \\
(-1.803)\end{array}$ & \\
\hline \multicolumn{2}{|c|}{ Industry dummy3 } & $\begin{array}{c}-.233 * \\
(-4.447)\end{array}$ & $\begin{array}{c}-.188 * \\
(-4.099)\end{array}$ & $\begin{array}{c}-.152 * \\
(-2.954)\end{array}$ & $\begin{array}{c}-.107 * * \\
(-2.481)\end{array}$ & $\begin{array}{l}-.036 \\
(-.901)\end{array}$ & \\
\hline \multicolumn{2}{|c|}{ Work Characteristic } & $\begin{array}{c}1.08^{*} \\
(2.331) \\
\end{array}$ & $\begin{array}{c}.076^{*} \\
(1.887) \\
\end{array}$ & $\begin{array}{c}1.02 * \\
(2.260) \\
\end{array}$ & $\begin{array}{c}.059 \\
(1.571) \\
\end{array}$ & $\begin{array}{l}.031 \\
(.886) \\
\end{array}$ & \\
\hline \multirow{2}{*}{ Relationship } & Communication & & $\begin{array}{c}.039 \\
(.554) \\
\end{array}$ & & $\begin{array}{l}.030 \\
(.455) \\
\end{array}$ & $\begin{array}{l}.016 \\
(.254)\end{array}$ & All R \\
\hline & Trust & & $\begin{array}{c}.240 * \\
(3.130) \\
\end{array}$ & & $\begin{array}{c}.140 \\
(1.944) \\
\end{array}$ & $\begin{array}{l}.050 \\
(.747) \\
\end{array}$ & $\mathrm{S}$ in JS \\
\hline \multirow{4}{*}{$\begin{array}{l}\text { Organizational } \\
\text { Culture }\end{array}$} & Innovation & & $\begin{array}{l}.055 \\
(.864) \\
\end{array}$ & & $\begin{array}{c}.075 \\
(1.252)\end{array}$ & $\begin{array}{l}.055 \\
(.988)\end{array}$ & All R \\
\hline & Relation & & $\begin{array}{c}.210 * \\
(3.439) \\
\end{array}$ & & $\begin{array}{c}.284 * \\
(4.942) \\
\end{array}$ & $\begin{array}{c}.205 * \\
(3.835) \\
\end{array}$ & All $\mathrm{S}$ \\
\hline & Hierarchy & & $\begin{array}{c}-.029 \\
(-.687)\end{array}$ & & $\begin{array}{c}-.099^{*} \\
(-2.460)\end{array}$ & $\begin{array}{c}-.088 * \\
(-2.380)\end{array}$ & $\begin{array}{c}\text { All R } \\
\text { (negative in } \\
\text { OC) } \\
\end{array}$ \\
\hline & Rational & & $\begin{array}{l}.031 \\
(.570) \\
\end{array}$ & & $\begin{array}{l}.111^{*} \\
(2.177) \\
\end{array}$ & $\begin{array}{c}.099 * \\
(2.124) \\
\end{array}$ & $\mathrm{S}$ in $\mathrm{OC}$ \\
\hline \multicolumn{2}{|l|}{ Job Satisfaction } & & & & & $\begin{array}{c}.377 * \\
(8.997) \\
\end{array}$ & Some S \\
\hline \multicolumn{2}{|c|}{ Adjusted $\mathrm{R}^{2}$} & .094 & .332 & .133 & .407 & .500 & \\
\hline \multicolumn{2}{|l|}{$\mathrm{F}$} & 6.700 粦 & $16.679 *$ & $9.457 *$ & 22.578* & 30.414 * & \\
\hline
\end{tabular}

Note: $* 0.01, *<0.05, \mathrm{H}=$ Hypothesis, $\mathrm{R}=$ Rejected, $\mathrm{S}=$ Supported, JS=Job Satisfaction, OC=Organizational Commitment

Job satisfaction results show that explanation rate (Adjusted $\mathrm{R}^{2}$ ) increased from M1 9.4\% to M2 33.2\% and all empirically significant model(F). This implies relationship variables and organizational culture variables explain more compare to demographic variables. Results show that among the demographic variables industry and work characteristics are empirically significant. Compare to Finance industry, job satisfaction of Insurance \& Pension industry (-.129) and Finance \& Insurance Service industry (-.188) is low. And as work characteristic show positive (.076) influence implies that as work is routinely repeated to novelty increase job satisfaction. In this study, work characteristics show empirically significant influence on job satisfaction opened possibility of group differentiation 
of work characteristics. Later path analysis by group comparison among work characteristic is analyzed. Among relationship variable only trust (.240) give significantly positive effect which is concerted results of literature (Pincus, 1986; Belicki \& Woolcott, 1996; Dirks \& Ferrin, 2002). And among organizational culture variables only relation (.210) give significantly positive effect on job satisfaction.

Organizational commitment results show that the explanation rate increased from M1 13.3\%, M2 40.7\% to M3 50.0 and all empirically significant models. This implies job satisfaction; relationship variables and organizational culture variables explain more compare to demographic variables. Results show that all demographic variables and relationship variables are not significant. The biggest significant effect is from job satisfaction (.377) on organizational commitment. Which implies that to increase organizational commitment increase in job satisfaction is crucial. Among organizational culture variable, innovation is only variable which is no significant. Among empirically significant variables, relation (.205) and rational (.099) give positive effect yet hierarchy (-.088) give negative effect on organizational commitment.

Based on the results the only supported hypothesis is 1-2 which is relation culture's positive influence on both job satisfaction and organizational commitment. Hypothesis 1-1, 1-3 and 2-1 are rejected. Moreover, result of hypothesis 1-3 relation showed opposite direction, hierarchy showed negative influence on organizational commitment. Hypothesis 1-4 and 2-2 is half supported(rejected). In hypothesis 1-4 rational culture give significantly positive influence on organizational commitment however not supported in job satisfaction. In hypothesis 2-2 trust give significantly positive influence on job satisfaction yet not supported in organizational commitment. Lastly in hypothesis 3 case, due to the mixed results of hypotheses 1 to 2, it could be explained as some support(reject).

\subsubsection{Path Analysis by Group Comparison among Work Characteristic}

Regression results in Table 3 show the significant effect of work characteristics on job satisfaction which is positive. In this study, work characteristic is measured as to how employees characterize their work is chosen as routinely repeat, often exceptional, sometimes exceptional, or everyday novelty. There can be a different influence on relationship and organizational culture depend on the employee's work characteristic group on organizational effectiveness. Therefore, in this study, the moderating effect of work characteristic using path analysis by group comparison is analyzed and the result is summarized in Table 4.

Table 4: Path Analysis of Organizational Effectiveness by Group Comparison of Job Characteristic

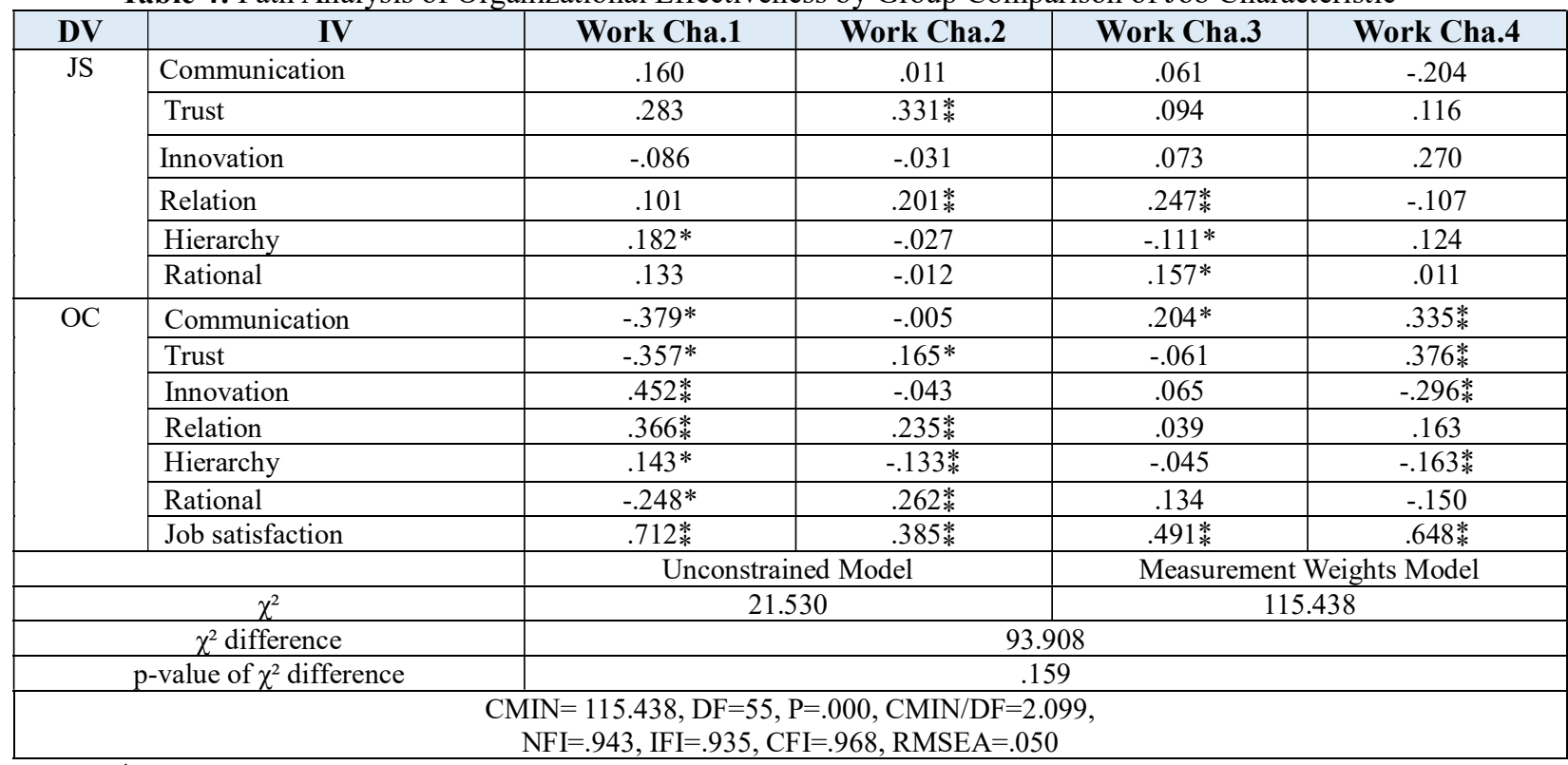

Note: $*<0.01, *<0.05, \mathrm{DV}=$ Dependent Variable, IV=Independent Variable, JS=Job Satisfaction, OC=Organizational Commitment 


\section{Conclusions}

Recalling the purpose of this research is to measure and analyze causal relation between employees HRM-related recognition like organizational effectiveness, relationship, organizational culture. Also, in this research mediation of job satisfaction and moderation of work characteristic is included as exploratively. Especially as the interest of financial aria increase in economic change and labor market change, this study focused on the employee of the financial aria in Korea. Based on the literature review, this study measured relationship variables with communication and trust. And measured organizational culture variable with innovation, relation, hierarchy and rational. Also, organizational effectiveness with job satisfaction and organizational commitment. This study used 442 financial aria employees in 7th HCCP of KRIVET.

The completion of the study expands the academic perspective. First, this study expanded to organizational culture on organizational commitment. Most literature is focused on organizational culture on job satisfaction (Robbins, 1998; Kraut, 1998; Bellou, 2010; Tsai, 2011; Belias \& Koustelios, 2014). Also, statistical expand the application to employees of the financial aria in Korea. Second, is relationship and organizational culture on organizational effectiveness. This study helps relationship research expand to the research of communication and trust also internal marketing. And helps organizational effectiveness research expand to the research of job satisfaction and organizational commitment. Third, work characteristic differentiation on organizational effectiveness. Literature has continuously shown the role of work characteristics mostly as the mediator (Parker, 2003; Kim et al., 2009) however new possible role is suggested from this study result.

The contribution of this study reaching practical implications in business management and HRM. First, this research conformed a reliable measure of effectiveness-job satisfaction and organizational commitment, relationshipcommunication and trust, organizational culture-innovation, relation, hierarchy, rational. This supports research better understanding of concept and application. Second, this study result gives insight into the presence of relationship and organizational culture among financial aria. Third, as a contradictory result suggest, management differentiation need to be considered between work characteristic. Especially, routinely repeat work and others showed very opposite results therefore the different and cautious approach is necessary.

The limitation does exist. First, sample convenience limits generalizability. The respondents are not equally represented in demographic characteristics. Therefore, future research should broaden the sample size and collect a matching sample. Second, the data used in this study is $7^{\text {th }}$ HCCP in KRIVET therefore needs to be updated. However, since KRIVET no longer collects HCCP anymore other substitute or data collection is in need. Third, there still a black box between relationships and hazy explaining relationships. Therefore, other antecedents' analysis is needed.

\section{References}

Allen, N. J., \& Meyer, J. P. (1990). The measurement and antecedents of affective, continuance and normative commitment to the organization. Journal of Occupational Psychology, 63(1), 1-18.

Allert, J., \& Chatterjee, S. (1997). Corporate communication and trust in leadership. Corporate Communications: And International Journal, 2(1), 14-21.

Anderson, J., \& Narus, J. (1984). A model of the distributor's perspective of distributor-manufacturer working relationships. Journal of Marketing, 48(4), 62-74.

Aycan, Z., Kanungo, R. N., \& Sinha, B. (1999). Organizational culture and human resource management practices: The model of culture fit. Journal of Cross-Cultural Psychology, 30(4), 501-526.

Belias, D., \& Koustelios, A. (2014). Organizational culture and job satisfaction: A review. International Review of Management and Marketing, 4(2), 132-149.

Belicki, K., \& Woolcott, R. (1996). Employee and patient designed study of burnout and job satisfaction in a chronic care hospital. Employee Assistance Quarterly, 12(1), 37-45.

Bellou, V. (2010). Organizational culture as a predictor of job satisfaction: the role of gender and age. Career Development International, 15(1), 4-19.

Boshoff, C., \& Tait, M. (1996). Quality perceptions in the financial service sector the potential impact of internal marketing. International Journal of Service Industry Management, 7(5), 5-31. 
Buchanan, B. (1974). Building organizational commitment: The socialization of managers in work organizations. Administrative Science Quarterly, 19(4), 533-

Cameron, K. S. (1985). Cultural congruence, strength, and type: relationships to effectiveness. ASHE 1985 Annual Meeting Paper.

Cameron, K. S., \& Quinn, R. E. (2011). Diagnosing and Changing organizational culture: based on the competing values framework (3th edition.ed.). San Francisco, CA: Jossey-Bass.

Campbell, J. P. (1977). On the nature of organizational effectiveness, in P. S. Goodman, J. M. Pennings \& Associated (Eds), New Perspectives on Organizational Effectiveness, CA: Jossey-Bass.

Choi, S. U. (2005). A stud on the organizational culture profile in the Korean central government. Korean Public Administration Review, 39(2), 41-62.

Cote, S., \& Morgan, L. (2002). A longitudinal analysis of the association between emotional regulation, job satisfaction, and intention to quit. Journal of Organizational Behavior, 23, 947-962.DOI: 10.1002/job.174.

Chu, G. W., \& Jung, J. H. (2020). Impact of internal marketing on job satisfaction, job involvement, customer orientation and job performance of employee in securities firms' branch. Journal of Korea Contents Association 20(5), 476-499.

De Ridder, J. A. (2006). Organizational communication and supportive employees. Human Resource Management Journal, 14(3), 20-30.

Deutschman, M. T. (2005). An ethnographic study of nursing home culture to define organizational realities of culture change, Journal of Health and Human Services Administration, 28(2), 246-281. DOI: 10.2307/41288066.

Dirks, K. T. \& Ferrin, D. L. (2002). Trust in leadership: meta analytic findings and implications for research and practice. Journal of Applied Psychology, 87(4), 611-628.

Etzioni, A. (1960). Two approaches to organizational analysis: A critique and a suggestion. Administrative Science Quarterly, 5(2), 257-273.

Ginzburg, E. S. (1981). Within the whirlwind. N Y: Harcourt Brace Jovanovich.

Griffin, R. W., \& Moorhead, G. (2009). Organizational behavior: managing people and organizations (9th ed.). Boston: Houghton Mifflin.

Guzley, R. M. (1992). Organizational climate and communication climate predictors of commitment to the organization. Management Communication Quarterly, 5(4), 379-402.

Herzberg, F. , Mausner, B., \& Snydernma, B. B. (1959). The motivation to work NY: John Wiley \& Sons. Inc.

Hofstetter, H., \& Harpaz, I. (2015). Declared versus actual organizational culture as indicated by an organization's performance appraisal. The International Journal of Human Resource Management, 26(4), 445-466.

Hogan, S. J., \& Coote, L. V. (2014). Organizational culture, innovation, and performance: a test of Schein's model. Journal of Business Research, 67(8), 1609-1621.

Hoppock, R. (1935). Job Satisfaction. NY: Harper \& Row.

Jaskyte, K., \& Dressler, W. W. (2004). Studying culture as an integral aggregate variable: organizational culture and innovation in a group of nonprofit organizations. Field Methods, 16, 265-284.

Jassawalla, A. R., \& Sashittal, H. C. (2002). Cultures that support product-innovation processes. Academy of Management Perspective, 16(3), 42-54.

Ju, Y. H., \& Sun, M. J. (2018). The effect of organization culture on job satisfaction: focusing on the mediating effect of communication. Journal of Digital Convergence, 16(7), 153-164.

Kiffin-Pertersen, S. A. \& Cordery, J. L. (2003). Trust, individualism and job characteristics as predictors of employee preference of teamwork. International Journal of Human Resource Management, 14(1), 93-116.

Kim, H. J., Knight, D. K., Crutsinger, C. (2009). Generation Y employees' retail work experience: the mediating effect of job characteristics. Journal of Business Research, 62(5), 548-556.

Kim, J. H. (2007. The relationship between organizational culture, organizational commitment and performance: an examination of public employment service. Quarterly Journal of Labor Policy, 7(2), 103-134.

Kim, Y. J. (2000). Longitudinal study on the change of organizational culture and performance in Korean firms. Korean Journal of Management, 8(2), 111-134.

Kraut, A. (1998). Job satisfaction: appreciation, assessment, cause, and consequences. Personnel Psychology, 51(2), 513.

Lee, J. E., \& Lee, Y. J. (2008). The effect of organizational culture types on organizational commitment: Kimberly \& Quinn's model. Kora Policy Journal, 8(8), 60-80.

Levering, R. (2000). A great place to work, what makes some employers so good (and most so bad). New York: 
Random House.

Locke, E. A. (1969). What if job satisfaction? Organizational Behavior and Human Performance, 4(4), $309-336$.

Locke, E. A. (1976). The nature and causes of job satisfaction in Donnette. Handbook of Industrial \& Organizational Psychology, IL: Rand McNally.

Mesfin, D., Woldie M, Adamu, A., \& Bakele, F. (2020). Perceived organizational culture and its relationship with job satisfaction in primary hospitals of Jimma zone and Jimma town administration, correlational study. BMC Health Services Research, 20, 2-9. https://doi.org/10.1186/s12913-020-005319-x

Meyer, M. S. (1964). Who are you inactivated worker? Harvard Business Review, 42.

Nunnally, J. C, \& Bernstein, I. H. (1994). Psychometric theory (3 ${ }^{\text {rd }}$ ed.). New York, NY: McGraw-Hill.

O'Reilly, C. A., Chatman, J., \& Caldwell, D. F. (1991). People and organizational culture: a profile comparison approach to assessing person-organization fit. Academy of Management Journal, 34(3), 487-516.

Osborne, R. N., Hunt, J. G., \& Cach, L. R. (1980). Organization theory. NY: John Willey \& Sons.

Parker, S. K. (2003). Longitudinal effects of lean production on employee outcomes and the mediating role of work characteristics. Journal of Applied Psychology, 88(4), 620-634. https://doi.org/10.1037/0021-9010.88.4.620.

Parker, R., \& Bradley, L. (2000). Organizational culture in the public sector: evidence from six organizations. International Journal of Public Sector Management, 13(2), 125-141.

Porter, L. W., \& Steers, R. M. (1974). Organizational commitment, job satisfaction and turnover among psychiatric technicians. Journal of Applied Psychology, 59(5), 603-615.

Price, J. L. (1972). The study of organizational effectiveness. The Sociological Quarterly, 13(1), 3-15.

Price, J. L., \& Mueller, C. W. (1986). On the causal ordering of job satisfaction and organizational commitment. Academy of Management Journal, 29(4), 847-858.

Quinn, R. E., \& Kimberly, J. R. (1984). Paradox, planning, and perseverance: guidelines for managerial practice. Managing organizational transitions. Homewood, IL: Richard D. Irwin.

Robbins, S. P. (1998). Organization behavior: concepts, controversies, and applications. NI: Prentive Hall.

Rosli, M., \& Hussein, A. (2008). Communication climate and organizational performance, paper presented to the 8th International Conference on Knowledge, Culture \& Changes in Organizations, 5-8 August, 2008 Cambride University (UK).

Ruppel, C., \& Harrington, S. (2000). The relationship of communication, ethical work climate and trust to commitment and innovation. Journal of Business Ethics, 25(4), 318-328.

Sarhan, N., Harb, A. Shrafat, F., \& Alhusban, M. (2020.) The effect of organizational culture on the organizational commitment: evidence from hotel industry. Management Science Letters, 10, 183-196. Doi: 10.5267/j.ml.2019.8.004

Schein, E. H. (1985). Defining organizational culture. Classics of Organization Theory, 3(1), 490-502.

Skarlicki, D., \& Dirks, K. (2001). Leader as a builder of trust. HR. Com [On-line Serial].

Steers, R. M. (1975). Problems in the measurement of organizational effectiveness. Administrative Science Quarterly, 20(4), 546-558.

Steers, R. M. (1977). Antecedents and outcomes of organizational commitment. Administrative Science Quarterly, $22(1), 46-56$.

Tsai, Y. (2011). Relationship between organizational culture, leadership behavior and job satisfaction. BMC Health Services Research, 98(11), 2-9. Doi:: 1472-6963/11/98.

Vilnai-Yavetz, I., Rafaeli, A., \& Yaacov, C. S. (2005). Instrumentality, aesthetics, and symbolism of office design. Environment and Behavior, 37(4), 533-551.

Vroom, V. H. (1964). Work and Motivation. NY: Wiley.

Williams, R. (1983). Keywords: a vocabulary of culture and society (Rev. ed.) London: Flamingo.

Zammuto, R. F., \& Krakower, J. Y. (1991). Quantitative and qualitative studies of organizational culture. CT: JAI Press Inc. 


\section{Appendix 1}

\begin{tabular}{|c|c|c|}
\hline Variable & Item & Estimate \\
\hline \multirow{3}{*}{ Communication } & $\mathrm{c} 1$ & Company inform employee about company information in detail. \\
\hline & $\mathrm{c} 2$ & In company, on can deliver opinion freely to supervisor \\
\hline & $\mathrm{c} 3$ & Communication between department goes well \\
\hline \multirow[t]{3}{*}{ Trust } & $\mathrm{t} 1$ & Cowers trust each other \\
\hline & $\mathrm{t} 2$ & Evaluation and reward is fairly treated \\
\hline & t3 & Company board members are trustworthy \\
\hline \multirow{3}{*}{ Innovation } & i1 & Company encourage change and new attempt \\
\hline & $\mathrm{i} 2$ & Company deliver proper reward on innovation \\
\hline & i3 & Company prefer creative person than sincere person \\
\hline \multirow{3}{*}{ Relation } & $\mathrm{r} 1$ & Familyhood is in the air in company \\
\hline & r2 & Company value unity and harmony \\
\hline & r3 & Company value teamwork \\
\hline \multirow[t]{3}{*}{ Hierarchy } & h1 & Information and decision-making flow from top to bottom \\
\hline & h2 & Sense of hierarchy is in company \\
\hline & h3 & Formalizing procedure, regulation and policy in important \\
\hline \multirow[t]{3}{*}{ Rational } & $\mathrm{j} 1$ & Company emphasize competition mood and performance achievement \\
\hline & $\mathrm{j} 2$ & Company emphasize professional knowledge and competence of work \\
\hline & $\mathrm{j} 3$ & Evaluation is based on job competency and performance \\
\hline \multirow[t]{3}{*}{ JS } & s1 & Satisfied with current work \\
\hline & s2 & Satisfied with current pay check \\
\hline & s3 & Satisfied with current human relation in job \\
\hline \multirow[t]{4}{*}{$\mathrm{OC}$} & $\mathrm{c} 1$ & Will consider changing job if better condition is offered \\
\hline & $\mathrm{c} 2$ & Feel company problem as my own \\
\hline & $\mathrm{c} 3$ & Will lose much if I decide to leave company \\
\hline & $\mathrm{c} 4$ & Loyal to company is worthy \\
\hline
\end{tabular}

